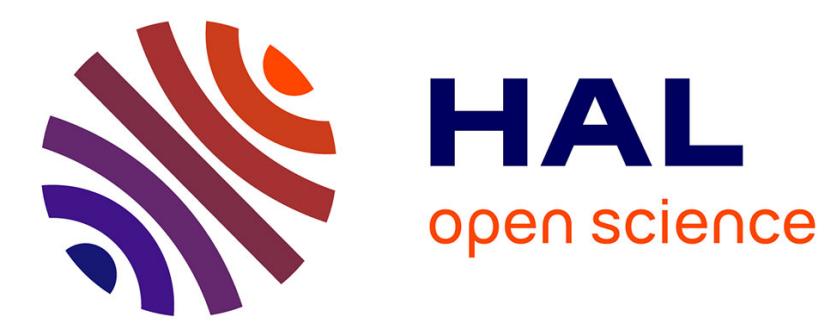

\title{
Controls, budgets and variability of riverine sediment fluxes to the Gulf of Lions (NW Mediterranean Sea)
}

Mahrez Sadaoui, Wolfgang Ludwig, François Bourrin, Patrick Raimbault

\section{To cite this version:}

Mahrez Sadaoui, Wolfgang Ludwig, François Bourrin, Patrick Raimbault. Controls, budgets and variability of riverine sediment fluxes to the Gulf of Lions (NW Mediterranean Sea). Journal of Hydrology, 2016, 540, pp.1002-1015. 10.1016/j.jhydrol.2016.07.012 · hal-01357640

\section{HAL Id: hal-01357640 \\ https://hal-univ-perp.archives-ouvertes.fr/hal-01357640}

Submitted on 13 Jan 2022

HAL is a multi-disciplinary open access archive for the deposit and dissemination of scientific research documents, whether they are published or not. The documents may come from teaching and research institutions in France or abroad, or from public or private research centers.
L'archive ouverte pluridisciplinaire HAL, est destinée au dépôt et à la diffusion de documents scientifiques de niveau recherche, publiés ou non, émanant des établissements d'enseignement et de recherche français ou étrangers, des laboratoires publics ou privés.

\section{(ㄷ)(1) $\$$}

Distributed under a Creative Commons Attribution - NonCommerciall 4.0 International 


\title{
Controls, budgets and variability of riverine sediment fluxes to the Gulf of Lions (NW Mediterranean Sea)
}

\author{
Mahrez Sadaoui ${ }^{\mathrm{a}, \mathrm{b}, *}$, Wolfgang Ludwig ${ }^{\mathrm{a}, \mathrm{b}}$, François Bourrin ${ }^{\mathrm{a}, \mathrm{b}}$, Patrick Raimbault ${ }^{\mathrm{c}}$ \\ a Université de Perpignan Via Domitia, Centre de Formation et de Recherche sur les Environnements Méditerranéens, UMR 5110, 52 Avenue Paul Alduy, \\ F-66860 Perpignan cedex, France \\ ${ }^{\mathrm{b}}$ CNRS, Centre de Formation et de Recherche sur les Environnements Méditerranéens, UMR 5110, 52 Avenue Paul Alduy, F-66860 Perpignan cedex, France \\ ' Institut Méditerranéen d'Océanologie, MIO, Campus de Luminy, 162 Avenue de Luminy, F-13288 Marseille cedex 9, France
}

\begin{abstract}
The present study investigates the spatio-temporal variability of riverine sediment fluxes to the Gulf of Lions, one of the most extensive shelf regions in the Mediterranean Sea. Small coastal rivers compete here with the Rhone River, nowadays the largest Mediterranean river in terms of water discharge. Our scientific objectives were to investigate the major controls of riverine sediment yields (SY) in this area and to quantify the role of the small coastal rivers, largely ignored in previous studies, in the total sediment budgets. Another objective concerned the source identification of the Rhone sediments with regard to the major tributary contributions, and to test whether the sediment fluxes are in equilibrium in the basin. For the calculation of representative long-term fluxes, we used a Simplified Rating Curve Approach (SiRCA) which could be validated by high resolution monitoring and existing literature data. An overall of 13 drainage basins could be distinguished, covering about $86 \%$ of the study area (6 coastal rivers, the Rhone River, and 6 of its tributaries). Representative SY range from 19 to $151 \mathrm{t} \mathrm{km}^{-2} \mathrm{yr}^{-1}$ in the investigated drainage basins. Despite their smaller basin areas and more torrential discharge regimes, SY of the coastal rivers were generally lower compared to SY of the Rhone River and its tributaries. Confrontation with the lithological, morphological and hydroclimatic basin characteristics indicate that lithology exerts the dominant control on SY in the study region. In particular, the existence of erodible sedimentary rocks in the headwater regions yields high SY. Peak values of 135 and $151 \mathrm{t} \mathrm{km}^{-2} \mathrm{yr}^{-1}$ were observed for the Isere and Durance tributaries of the Rhone River, where badlands exist. The coastal rivers contribute on average only to slightly more than $5 \%$ of the long-term sediment inputs to the Gulf of Lions. During individual years however, their contribution can strongly increase (up to $27 \%$ in 2011). Their contribution is generally important during late spring and autumn, when flash-floods are frequent (up to $90 \%$ of the monthly sediment discharge). Summing the various tributary contributions of the Rhone River produces a sediment budget that is close to the sediment export at the river mouth. This indicates that at spatial scales, the average sediment fluxes are equilibrated in the basin. About $40 \%$ of the Rhone sediments originate from the Isere and Durance tributaries. However, fully closure of the budgets requires high SY in the lowermost basin parts. Omitting in our calculations only a few years with exceptional flooding considerably reduce these values. Trend analyses show at the same time that the sediment fluxes from the Saone and Isere tributaries decreased during the study period. At temporal scales, sediment transport from upstream to downstream was therefore not in equilibrium and the remobilisation of older sediments from the downstream basin parts may have been important.
\end{abstract}

\section{Introduction}

Riverine sediment yields (sediment fluxes divided by basin area) can be highly variable among the various river systems on

* Corresponding author at: Université de Perpignan Via Domitia, Centre de Formation et de Recherche sur les Environnements Méditerranéens, UMR 5110, 52 Avenue Paul Alduy, F-66860 Perpignan cedex, France.

E-mail address: sadaoui.mahrez@gmail.com (M. Sadaoui).
Earth and, despite an increasing amount of data and studies during recent decades (Walling and Webb, 1985; Ludwig and Probst, 1998; Harrison, 2000; Meybeck et al., 2003; Walling and Fang, 2003; Delmas et al., 2009, 2012; Raux et al., 2011; Cheviron et al., 2014; Gay et al., 2014), the identification of their major controls is still a matter of debate. Small rivers can be more efficient in the evacuation of freshly eroded materials, attributing greater sediment delivery ratios (according to Walling (1983a,b), the ratio 
between bulk erosion in the basin and sediment supply at the basin outlet) to these rivers compared to large river systems. In combination with greater relief and increased rainfall, small mountainous rivers have consequently been proposed to deliver a large fraction of the global sediment discharge to the oceans (Milliman and Syvitski, 1992). Moreover, because of more event-dominated discharge regimes (e.g. flash-floods), particulates derived from these rivers may behave differently in the coastal zone in terms of burial rates and/or further offshore transport towards the deep sea. Geochemical budgets on associated carbon, nutrient and pollutant fluxes may therefore need revision compared to previously established numbers which mainly refer to observations on large river systems.

The Mediterranean Sea is surrounded by mountain belts and small coastal rivers are numerous in its drainage basin (Ludwig et al., 2003). Its climate is characterized by a pronounced seasonality and therefore considered to be in favour of enhanced mechanical erosion of soils (de Vente et al., 2008; Delmas et al., 2009). The Gulf of Lions (GoL) located in the North-Western (NW) Mediterranean is an interesting framework for the study of riverine sediment yields. On the one hand, sediment fluxes from small coastal rivers can here be compared to the fluxes of the Rhone River, nowadays the biggest Mediterranean river in terms of freshwater discharge (Ludwig et al., 2009). On the other hand, the GoL is one of the most extensive shelf regions in the Mediterranean Sea and has been intensively studied in terms of its particulate matter dynamics from the near shore down to the deep sea environments (e.g., Bourrin et al., 2008; Durrieu de Madron et al., 2000, 2009; Roussiez et al., 2012). This offers the possibility to achieve a holistic vision on particulate matter fluxes in a source-to-sink prospective, covering both particle mobilisation in the terrestrial source regions and their final deposition in the shelf and deep water sinks.

Up to now, the representative suspended particulate matter (SPM) fluxes for the entire GoL drainage basin were difficult to obtain because of the lack of data. In particular for the coastal rivers with pulsing discharge regimes, monitoring data were missing and considerable uncertainty remained about the long term fluxes. Since the late 1990 , however, several research programs got interested in these river systems, some were studied more in detail (Serrat, 1999; Serrat et al., 2001; Petelet-Giraud and Negrel, 2007) and first data compilations could be produced (Bourrin et al., 2006). Long-term monitoring of the Tet and Rhone rivers was established and integrated in the French oceanographic observation system MOOSE (Dumas et al., 2015). Based on these efforts, data availability considerably increased. We therefore attempt a new and more complete synthesis on riverine sediment fluxes in this region. We first applied a simple and robust method for the calculation of average fluxes in the different drainage basins which could be validated by high resolution monitoring data. This method does not only produce representative long-term fluxes for all major drainage basins, but also permits a breakdown of the sediment discharge from the Rhone River into its major tributary contributions. We then discuss the variability of the sediment yields on the basis of their various drainage basin characteristics in order to identify the major controls of riverine sediment yields in this region. Finally, we produce hind-casting scenarios on the inter-annual and seasonal variability of the SPM fluxes from the coastal rivers in comparison to those of the Rhone River.

\section{Regional settings}

The Gulf of Lions is a crescent-shaped passive margin located in the NW Mediterranean Sea, extending from the northern Spanish border to the city of Toulon in south-eastern France. Its terrestrial drainage basin covers an area of about $125,000 \mathrm{~km}^{2}$, morphologi- cally constrained by the Alps in the East, the Massif Central in the North-West and the Pyrenees in the South.

Almost $80 \%$ of this area is composed by the Rhone River basin (Fig. 1). It is characterized by a dominant South to North orientation and stretches far outside the Mediterranean climate type. As a consequence, water discharge regimes of the Rhone are not homogeneous and can have glacial, nival, pluvial and Mediterranean components (Pont et al., 2002). The strong topographic gradients and the abundant water resources in the basin led to the construction of 66 hydroelectric dams on the main river course and its tributaries (Ollivier et al., 2010). In the Mediterranean basin part, irrigation can also affect water discharge. Although damming and hydroelectric power generation normally have only minor impacts on the long term water discharge, there exists a notable exception in the South: a considerable part of the water discharge of the Durance tributary was bypassed to the Mediterranean Sea (via the Berre lagoon near Marseille) in the 1960s, leading to an overall reduction of the Rhone discharge of about $100 \mathrm{~m}^{3} / \mathrm{s}$ (Vivian, 1989).

A series of much smaller coastal rivers are located along the coast of the GoL west and south of the Rhone River. Neglecting the very small ones, these are the Herault, Orb, Aude, Agly, Tet and Tech rivers (Fig. 1a). Their hydroclimatic functioning is dominated by Mediterranean climatic conditions. Short and violent flash-floods exert a strong control on the average water and sediment transport. Despite the restricted areas of these rivers (together they cover less than $15 \%$ of the Gulf of Lions drainage basin), local climatic heterogeneity can be important (Lespinas et al., 2009). Only the Herault and Orb river basins are entirely characterized by Mediterranean climate type conditions whereas the river basins further to the south also depict temperate and even nival regimes in their headwater regions. All six coastal rivers depict clear signs of decreasing water discharge trends in relation to recent climate change (Lespinas et al., 2009, 2014). This is not the case for the Rhone River, where clear long-term trends are absent (Ludwig et al., 2009).

In our study, we consequently distinguished a total of 7 river basins ( 6 coastal rivers and the Rhone). For all of them, data for the calculation of representative SPM fluxes exist (see Section 3.2). In the case of the Rhone River, these data are also available for the major tributaries further upstream (Saone, Upper Rhone, Isere, Durance Ardeche and Ceze tributaries). We therefore considered them as 6 additional hydro-sedimentary units in our approach, allowing us to attempt a breakdown of the Rhone SPM fluxes according to the different source regions (Fig. 1b). We finally included two downstream monitoring stations along the main Rhone River course, which added 3 more basins to our data set (dowstream Rhone 1, 2, and 3: DR1, DR2 and DR3). Sediment fluxes from these basins can only be calculated indirectly via subtraction of the sediment fluxes from further upstream, which naturally attributes greater uncertainties to these values. Consideration of these downstream basin parts is nevertheless interesting as it allows to test whether the overall sediment fluxes in the Rhone River basin can be balanced or not.

\section{Methods}

\subsection{Average drainage basin characteristics}

\subsubsection{Morphology, lithology and land use}

Delineation and morphological characterization of the studied drainage basin was done with the open source software QGIS (QGIS, 2015) on the basis of two different digital elevation models (DEM). We used the $25 \mathrm{~m}$ spatial resolution DEM BD Alti of the French National Geographic Institute (IGN, 2015) for the coastal 

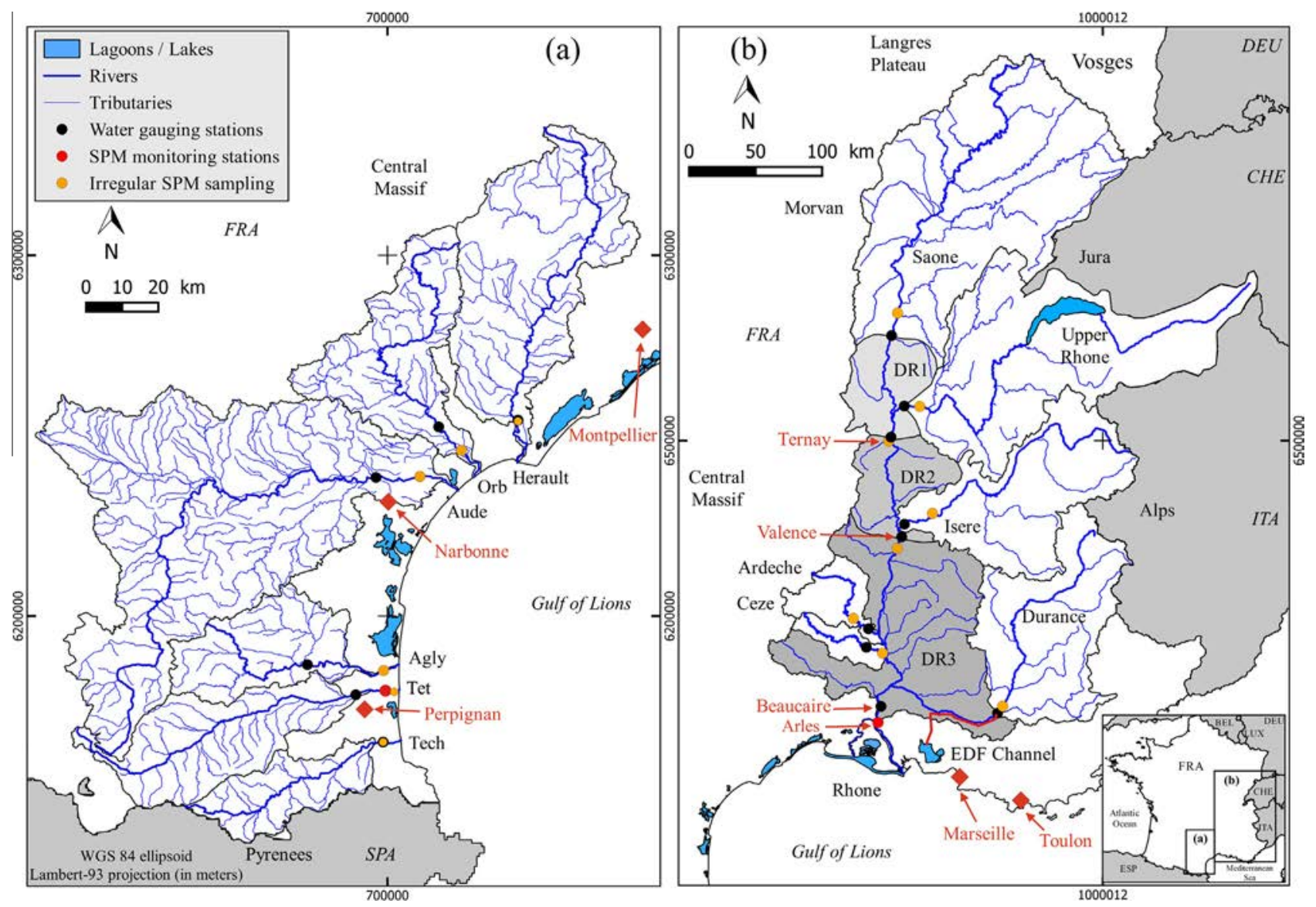

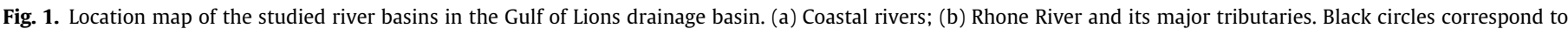

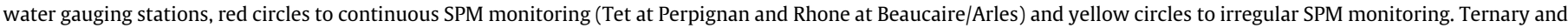

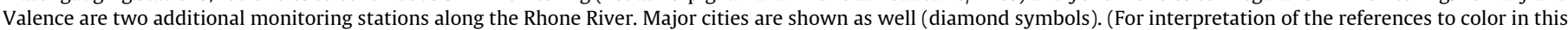
figure legend, the reader is referred to the web version of this article.)

rivers and the 30 arc-seconds spatial resolution (equivalent to about $1 \mathrm{~km}$ in our latitudes) DEM associated with the WorldClim data layers (see Section 3.1.2) for the Rhone River. Lithological information was taken from the SANDRE database (SANDRE, 2015) which distinguishes 13 major rock types with regard to their hydrogeological properties. We simplified them to 8 rock type classes. Finally, land use types were taken from the CORINE database (CLC, 2006) which is available from the European Environmental Agency in a $0.5 \mathrm{~km}$ spatial resolution. We simplified the individual units into 12 major classes.

Table 1 summarizes the morphological, lithological and land use characteristics of the studied river basins. Their respective areas (not considering the entire Rhone River) stretch from $723 \mathrm{~km}^{2}$ (Tech) to 25,932 $\mathrm{km}^{2}$ (Saone). Except the Ardeche and Ceze rivers, the Rhone tributaries have everywhere greater basins than the coastal rivers, but in both groups (small coastal rivers and Rhone sub-basins), particularly steep and elevated basins exist (e.g. the Tet, Isere and Durance basins). Although the outcropping rock types are highly variable in the study region, some regional and local peculiarities can be noticed. Plutonic and metamorphic rocks are dominant in the southernmost basins draining the Pyrenees (Tech and Tet). Limestones are abundant in the Agly, Herault, Saone and Upper Rhone basins, and mixed and faulted sedimentary rocks are dominant in the other basins. In the entire Rhone River basin, all major sedimentary rock types are equally represented (alluvials, limestones, detrial sedimentary rocks, mixed and faulted sedimentary rocks), but plutonic and metamorphic rocks are underrepresented compared to the coastal river basins. One should also notice the significant area portions of clays and marls in the Isere and Durance tributary basins. These rock types can lead to the formation of badlands (see Section 4.2).

Agricultural land use is significant in all drainage basins, covering up to $\geqslant 50 \%$ of the basin areas for the Aude and Saone rivers. Natural vegetation types are more abundant in the basins with high average elevation. In some of them (Ardeche, Agly and Tech), they cumulate to more than $70 \%$ of the total basin area.

\subsubsection{Water discharge and climate}

Data on water discharge $(Q)$ were obtained from the HYDRO database at the French Ministry of the Environment, centralizing most of the hydrological records in France (Hydro, 2015). Daily data were recovered for the most downstream gauging station in each basin, for which complete data series are available. Daily water discharges were then associated with daily-averaged SPM data (see Section 3.2). The series extend over the 1977-2013 period for the coastal rivers and over the 1969-2013 period for the Rhone and its tributaries. In some cases ( $4.0 \%$ of all data), data gaps exist in the time series. They were filled by applying linear interpolations from correlations with records from neighbouring stations according to Lespinas et al. (2009). These stations were chosen close to the main stations, avoiding the confluence of additional tributaries in between. Correlation coefficients were $r^{2} \geqslant 0.89$ in all cases. For the coastal rivers, filled data represent only $0.8 \%$ of all data and mainly concern the Herault (4.4\%) and Aude (1.0\%) rivers. For the Rhone tributaries, filled data represent $7.3 \%$. They are particularly abundant in the Saone and Upper Rhone tributaries 
Table 1

Morphological, lithological and land use drainage basin characteristics of the studied river basins.

\begin{tabular}{|c|c|c|c|c|c|c|c|c|c|c|c|c|c|}
\hline & Tech & Tet & Agly & Aude & Orb & Herault & Rhone & Saone & $\begin{array}{l}\text { Upper } \\
\text { Rhone }\end{array}$ & Isere & Durance & Ardeche & Ceze \\
\hline \multicolumn{14}{|l|}{ Morphology } \\
\hline Area $\left(\mathrm{km}^{2}\right)$ & 723 & 1373 & 1056 & 5292 & 1536 & 2580 & 96,364 & 25,932 & 20,315 & 12,022 & 10,834 & 2411 & 1384 \\
\hline Length (km) & 84 & 116 & 82 & 224 & 135 & 148 & 783 & 473 & 492 & 286 & 322 & 125 & 129 \\
\hline Elevation $(\mathrm{m})$ & 754 & 1057 & 448 & 427 & 395 & 367 & 784 & 368 & 1069 & 1445 & 1131 & 701 & 422 \\
\hline Maximum elevation (m) & 2722 & 2862 & 1839 & 2800 & 1122 & 1560 & 4498 & 1418 & 4498 & 3716 & 3560 & 1647 & 1472 \\
\hline Slope $\left(^{\circ}\right)$ & 7.6 & 8.2 & 5.6 & 3.6 & 4.7 & 3.6 & 6.1 & 1.8 & 8.7 & 12.5 & 7.9 & 5.1 & 3.2 \\
\hline \multicolumn{14}{|l|}{ Lithology (\%) } \\
\hline Alluvial and deltaic deposits & 16 & 14 & 4 & 7 & 4 & 6 & 17 & 10 & 19 & 22 & 8 & 9 & 3 \\
\hline Evaporites & 0 & 0 & 12 & 0 & 0 & 0 & 2 & 1 & 3 & 0 & 0 & 0 & 0 \\
\hline Limestones & 0 & 3 & 38 & 11 & 20 & 46 & 29 & 44 & 40 & 13 & 11 & 34 & 38 \\
\hline Clays and marls (badlands) & 0 & 0 & 0 & 0 & 0 & 0 & 9 & 0 & 0 & 18 & 15 & 0 & 0 \\
\hline Sandstones & 0 & 0 & 0 & 0 & 0 & 0 & 12 & 21 & 2 & 0 & 10 & 0 & 0 \\
\hline Mixed sedimentary (unfaulted) & 0 & 0 & 10 & 52 & 20 & 19 & 7 & 4 & 10 & 12 & 22 & 50 & 50 \\
\hline Mixed sedimentary (faulted) & 0 & 0 & 22 & 13 & 40 & 16 & 16 & 12 & 14 & 29 & 30 & 0 & 0 \\
\hline Plutonic and metamorphic rocks & 83 & 83 & 13 & 18 & 16 & 12 & 10 & 9 & 12 & 6 & 4 & 7 & 9 \\
\hline SR & 0.2 & 0.2 & 6.9 & 4.4 & 5.1 & 7.0 & 9.5 & 10.3 & 7.0 & 15.6 & 26.1 & 12.4 & 10.1 \\
\hline SRe & 0.0 & 0.2 & 5.2 & 3.5 & 4.5 & 5.0 & 7.1 & 8.9 & 5.7 & 15.5 & 23.0 & 11.4 & 9.3 \\
\hline \multicolumn{14}{|l|}{ Land use (\%) } \\
\hline Urban fabric & 2.5 & 4.1 & 0.9 & 2.0 & 2.8 & 2.3 & 3.7 & 4.0 & 6.7 & 2.5 & 1.4 & 2.5 & 4.1 \\
\hline Industrial unit & 0.0 & 0.7 & 0.2 & 0.7 & 0.7 & 0.3 & 0.9 & 0.8 & 1.9 & 0.7 & 0.4 & 0.0 & 0.7 \\
\hline Mine, dump and construction sites & 0.4 & 0.3 & 0.7 & 0.2 & 0.7 & 0.3 & 0.2 & 0.2 & 0.9 & 0.1 & 0.1 & 0.4 & 0.3 \\
\hline Arable land & 0.3 & 0.0 & 0.0 & 8.2 & 0.5 & 0.9 & 11.8 & 21.8 & 9.3 & 3.8 & 7.4 & 0.3 & 0.0 \\
\hline Permanent crops & 7.7 & 10.2 & 18.0 & 23.9 & 17.5 & 20.6 & 4.2 & 2.2 & 0.9 & 1.7 & 3.0 & 7.7 & 10.2 \\
\hline Pastures & 0.9 & 1.3 & 0.9 & 3.1 & 1.7 & 2.3 & 7.8 & 19.3 & 4.0 & 1.2 & 2.7 & 0.9 & 1.3 \\
\hline Heterogeneous agricultural areas & 9.8 & 7.8 & 7.8 & 14.5 & 11.9 & 8.4 & 18.3 & 18.7 & 23.4 & 15.1 & 9.9 & 9.8 & 7.8 \\
\hline Forests & 59.6 & 36.6 & 34.4 & 32.7 & 47.8 & 30.9 & 36.0 & 30.8 & 42.9 & 33.0 & 37.0 & 59.6 & 36.6 \\
\hline Scrub and/or herbaceous vegetation associations & 16.5 & 32.8 & 35.5 & 13.8 & 15.3 & 33.2 & 10.9 & 1.6 & 5.6 & 20.1 & 23.5 & 16.5 & 32.8 \\
\hline Open spaces with little or no vegetation & 2.3 & 6.1 & 1.6 & 0.7 & 1.1 & 0.8 & 6.0 & 0.5 & 3.9 & 21.8 & 14.6 & 2.3 & 6.1 \\
\hline Wetlands & 0.0 & 0.1 & 0.0 & 0.2 & 0.1 & 0.0 & 0.2 & 0.1 & 0.5 & 0.0 & 0.0 & 0.0 & 0.1 \\
\hline
\end{tabular}

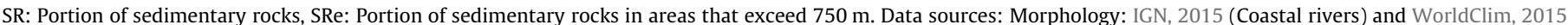
(Rhone); Lithology: SANDRE, 2015; Land use: CLC, 2006.

(>15\%), followed by the Ardeche (5.6\%), Durance (4.5\%) and Ceze (1.9\%) tributaries. In the case of the Upper Rhone, interpolations had to be done by correlation with the difference of two discharge records (Rhone at Ternay minus Saone), but even here, the corresponding correlation coefficient was high $\left(r^{2}=0.87\right)$.

In order to characterize the climatic conditions in the coastal river basins, we used the precipitation and temperature data from Lespinas et al. (2009, 2014). For the Rhone River and its tributaries, we extracted the average precipitation and temperature data from the WorldClim database (Hijmans et al., 2005). Available data consist in monthly data layers in a 30 arc-seconds spatial resolution and represent averages over the 1950-2000 period. All hydroclimatic parameters are summarized in Table 2 . We included an additional parameter which is supposed to reflect the torrential character of water discharge ( $\mathrm{Tr}$ ). It has been defined as the ratio of flood discharge (Qf) over mean annual discharge (Qmean). This requires a clear definition of what are flood and non-flood conditions, which is not a trivial task. We followed here the proposition of Dumas et al. (2015) and defined as flood discharge the threshold value corresponding to a return period of 1.4 years (based on the method of Gumbel, 1958). This return period has been selected because in the case of the Tet River, Qf then corresponds to about 10 times the average annual discharge, commonly considered to be the threshold for floods (Serrat et al., 2001). Notice that our definition of flood condition is purely based on statistical probability calculations, assuming that in all investigated river basins, floods do occur with the same temporal probability.

The $\mathrm{Tr}$ parameter clearly demonstrates the more variable discharge regimes of the coastal rivers compared to the Rhone River and its major tributaries. Only the Ceze and Ardeche tributaries have similar $\operatorname{Tr}$ values because of their smaller basin areas and their Mediterranean like climate types.

\subsection{Calculation of SPM fluxes}

Calculation of representative SPM fluxes was done through the fitting of rating curves to existing SPM - Q data pairs. These curves were then applied to the long term daily discharge records of the considered rivers. We compiled a large up-to-date database of Gulf of Lions rivers for this purpose (Table 3). Many of the data originate from the French water agency Agence de l'Eau RMC, which measures a series of water quality parameters monthly (AERMC, 2015). Whenever it was possible, we completed them using data from research studies which focussed on high discharge events. These data have been kindly supplied by the corresponding authors and concern the studies of Pont (1997) for the Rhone River, Serrat (1999) for the Agly River, Serrat et al. (2001) for the Tet River, and Petelet-Giraud and Negrel (2007) for the Herault River. We also added some unpublished data, in particular for the Tech River during flooding (Serrat, pers. com.). The largest data sets (about ten times the data volume compared to the other rivers) originate from continuous monitoring of the Tet and Rhone rivers which has been installed in the French oceanographic observation system MOOSE (Dumas et al., 2015).

Rating curves are widely used for the calculation of river sediment fluxes (for a general discussion, see for example Asselman, 2000). They are generally determined by least squares linear regression between the logarithmic (base 10) values of SPM concentration and discharge (in the following: log-log-p1 models). In some cases, however, second order polynomial regressions were applied to improve the data fitting (e.g. Serrat et al., 2001; Bourrin et al., 2006) and we tested these models as well (in the following: log-log-p2 models). We finally also tested a simplified rating curve approach (in the following: SiRCA models) for the calculation of SPM fluxes. Based on the long-term discharge 
Table 2

Hydroclimatic drainage basin characteristics of the studied river basins.

\begin{tabular}{|c|c|c|c|c|c|c|c|c|c|c|c|c|c|}
\hline & Tech & Tet & Agly & Aude & Orb & Herault & Rhone & Saone & Upper Rhone & Isere & Durance & Ardeche & Ceze \\
\hline $\mathrm{Qf}(\mathrm{mm})$ & 5739 & 2348 & 3107 & 1933 & 5432 & 6256 & 1555 & 1608 & 2330 & 2085 & 1188 & 4266 & 6198 \\
\hline $\mathrm{Q}$ mean $(\mathrm{mm})$ & 387 & 218 & 178 & 235 & 530 & 492 & 552 & 446 & 955 & 865 & 352 & 528 & 409 \\
\hline $\operatorname{Tr}$ & 15 & 11 & 17 & 8 & 10 & 13 & 3 & 4 & 2 & 2 & 3 & 8 & 15 \\
\hline Mean annual $\mathrm{P}(\mathrm{mm})$ & 878 & 780 & 824 & 848 & 1020 & 1089 & 988 & 1510 & 1239 & 1250 & 988 & 800 & 766 \\
\hline Pmax/Pmin & 2.5 & 2.2 & 3.3 & 2.7 & 0.5 & 0.4 & 5.3 & 4.6 & 4.6 & 3.1 & 3.5 & 1.6 & 1.5 \\
\hline $\mathrm{Q} / \mathrm{P}$ & 0.4 & 0.3 & 0.2 & 0.3 & 0.7 & 0.7 & 0.6 & 0.3 & 0.8 & 0.7 & 0.4 & 0.7 & 0.5 \\
\hline Mean annual $\mathrm{T}\left({ }^{\circ} \mathrm{C}\right)$ & 11.3 & 9.5 & 12.4 & 12.1 & 12.2 & 12.6 & 9.6 & 9.8 & 6.6 & 5.4 & 7.9 & 10.4 & 12.2 \\
\hline $\operatorname{Tmax}-\operatorname{Tmin}\left({ }^{\circ} \mathrm{C}\right)$ & 14.3 & 14.3 & 15.1 & 15.3 & 15.7 & 16.0 & 25.8 & 7.58 & 23.5 & 19.2 & 19.5 & 9.3 & 8.3 \\
\hline
\end{tabular}

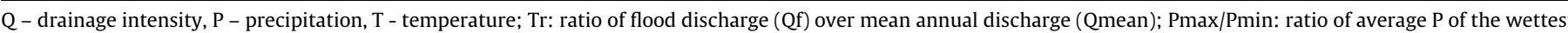

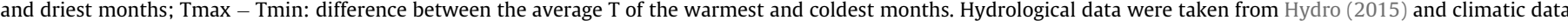
come from Lespinas et al. $(2009,2014)$ for the coastal rivers and from WorldClim (2015) for the Rhone and its tributaries.

records, we first performed statistical analysis of the mean daily discharge values for each river and created a series of discharge classes (Table 3 ) depending on how frequent they are (the classes have roughly equal importance in regards to the total water discharge of the studied rivers, except for the lowest and highest discharge classes). We then averaged the existing $\mathrm{Q}$ and SPM data within these classes and fitted the regressions to these averages. SiRCA models have the advantage that they strengthen in the regressions the weight of high discharge measurements which are particularly important for the calculation of realistic longterm fluxes. High discharge measurements are often underrepresented in data sets based on regular sampling frequencies.

Optimal fitting of SiRCA models always required the establishment of two separate regression lines for high and low discharge conditions, respectively (see Section 4.1). For this purpose, data points were separated into both groups following the method of Zeileis et al. (2003) and their associated R software routine. This method allows the detection of breakpoints (BP) in data series above and below of which regressions coefficients significantly change. In our approach, all data points with discharge values equal and greater the breakpoint discharge were used for fitting of the high discharge regression model and the rest of the points for the fitting of the low discharge regression model. Mathematical crossing of both regression lines consequently defines the switch point (SP) discharge above and below of which the corresponding regression model should be applied.

In some cases, SPM sampling sites did not exactly correspond to existing gauging stations (e.g. for the Tet river). In these cases we associated the closest water gauging station to them (Table 4), considering that SPM concentrations do not significantly change between both stations. Please note that for the reason of simplification, for flux calculations in the Tet River, we used only the discharge records of the station of Perpignan, although the total river discharge is usually considered to be the sum of this station and of the Basse River station (the last tributary of the river). Based on the data of Serrat et al. (2001), we found that omitting the Basse River discharge would only reduce the long-term SPM fluxes by about $4 \%$.

\subsection{Statistics}

\subsubsection{Tributary contributions to the Rhone discharge}

Pont et al. (2002) demonstrated that the flooding of the Rhone can be triggered in variable geographical source regions, resulting in different SPM concentrations for a given discharge value. In order to test whether our rating models can be improved by subsampling of SPM measurements according to the major tributary contributions during floods, we followed the authors approach and submitted the corresponding discharge series to a principal component analysis (PCA). The results (Fig. 2) allow the identification of three major discharge regimes in the Rhone River, named in the following as Northern floods (Saone, Upper Rhone), Mediterranean floods (Ardeche, Ceze) and South-Alpine floods (Durance, Isere).

\subsubsection{Error calculation}

Error estimates (Err) for the calculated SPM fluxes are determined by the square root of the variation coefficient (CV) between observed (FSPM) and modelled (FSPMm) instantaneous (i) SPM fluxes according to:

$$
\begin{aligned}
& \text { Err }=F S P M m \sqrt{\frac{\sum_{i=1}^{\mathrm{n}}\left(\mathrm{FSPM}_{\mathrm{i}} * \mathrm{CV}_{\mathrm{i}}^{2}\right)}{\sum_{\mathrm{i}=1}^{\mathrm{n}} \mathrm{FSPM}_{\mathrm{i}}}} \\
& \mathrm{CV}_{\mathrm{i}}=\frac{\mathrm{FSPM}_{\mathrm{i}}-\mathrm{FSPMm}_{\mathrm{i}}}{\mathrm{FSPM}_{\mathrm{i}}}
\end{aligned}
$$

\subsubsection{Multiple regression analyses}

Multiple regression analyses were used to investigate the relationships between the long-term average sediment yields and the corresponding drainage basin characteristics (Section 3.1). Analyses were carried out with the open source software R and its stepwise regression procedure (Chatterjee and Hadi, 2006), which alternates between backward and forward selections of a series of predictive variables to explain the given sediment yields. The retained variables in the regression model are selected on the basis of the $C_{P}$ criterion of Mallows (Mallows, 1973). It ensures that only those factors are included in the model for which the likelihood to gain accuracy increases sufficiently.

\subsubsection{Trend analysis}

In order to test whether the hydrosedimentary discharge patterns may have changed over time, we performed trend analyses for all records on the basis of the Mann-Kendall test (Mann, 1945; Kendall, 1975). More information on these tests can be found, for example, in Lespinas et al. (2009) and references therein.

\section{Results}

\subsection{Appropriate rating curve models}

High resolution monitoring of the Tet and Rhone rivers produced realistic SPM fluxes in both rivers during recent years (Dumas et al., 2015). It also offers the opportunity to test the performance of rating models on SPM transport in both rivers. We therefore overlaid the different rating curve models discussed above (log-log-p1, log-log-p2, SiRCA) on the plots of all individual data points which were used to fit the models, both for the Tet (Fig. 3a, c, e) and for the Rhone (Fig. 3b, d, f) rivers.

Fig. 3 reveals that in the case of the Tet River, neither the loglog-p1 nor the log-log-p2 models show optimal fits over the entire 


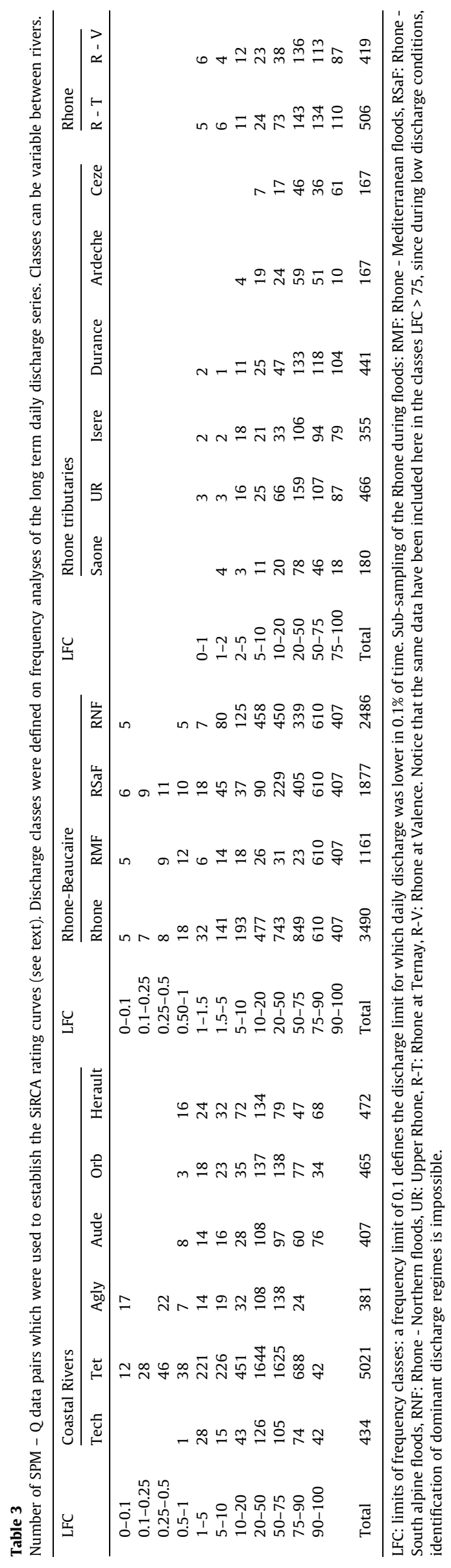

data range. The former underestimates the data under high discharge conditions whereas the latter overestimates them. Only the SiRCA lines hold a median position everywhere. In the case of the Rhone River, the same observations can be made, even if data fitting is better here and regression coefficients are greater than in the case of the Tet River.

Comparison of modelled and observed annual SPM fluxes in both rivers (Fig. 4a, b) confirm the weak performance of the classical rating models. For the Tet River, the log-log-p1 model generally underestimates the annual fluxes. The log-log-p2 model underestimates the fluxes during dry years, but overestimates them during wet years. SiRCA generally fits better with observations. For the Rhone River, discrepancies between models during individual years can be more important than for the Tet, but also here, SiRCA generally performs better than the log-log-p1 and log-log-p2 models. In some years (e.g. in 2006 and 2009), however, deviations with observations are important. Also compared to other literature models, SiRCA fits better with observations during most years, both in the Tet (Fig. 4c) and Rhone (Fig. 4d) rivers.

We therefore tested whether SiRCA models can also be successfully fitted to the other river stations. The results are synthesised in Fig. 5. Discharge units in this figure are $\mathrm{mm} \mathrm{day}^{-1}$, which allows direct comparison between rivers of different sizes. Although standard deviations can be important, average values perfectly fit on linear regression lines. Interestingly, in all cases the calculated switch points are situated in a narrow discharge range of about $0.5-2 \mathrm{~mm} \mathrm{~d}^{-1}$. During these conditions SPM transport probably switches from internal riverine sources to additional sediment supply via hillslope erosion. The existence of two rating curves is better visible in the small coastal rivers, where specific water discharge can drop to very low values. In the larger tributaries of the Rhone and the Rhone River itself, where discharge is more constant and maintained at higher levels, identification of a separate low discharge rating curve is less evident.

Notice that in Fig. 5, we also identified separate rating curve models for the Rhone River (RMF, RSAF and RNF plots) depending on the dominant discharge regimes (see Section 3.3.1). For a given discharge value, South-Alpine floods have the highest SPM concentrations, followed by Mediterranean floods and then by Northern floods. When they are individually selected according to the tributary discharge conditions (SiRCA-flood), modelled SPM fluxes now fit much better with observations in Fig. $4 \mathrm{~d}$.

\subsection{Variability and controls of sediment yields in the study area}

SiRCA was consequently retained as the most appropriate rating curve model in our study. As reference period for the flux calculations, we selected 1977-2013 for which the overall discharge records were complete (or poorest in data gaps). The resulting sediment yields (SY) are listed in Table $5 \mathrm{a}$ and give a complete picture of the spatial variability of average sediment yields in the Gulf of Lions drainage basin. They are compared to previous literature estimates whenever they exist (see Table $5 b$ ).

SY vary almost within one order of magnitude, from $19 \mathrm{t} \mathrm{km}^{-2}$ $\mathrm{yr}^{-1}$ (Aude) to $151 \mathrm{t} \mathrm{km}^{-2} \mathrm{yr}^{-1}$ (Durance). They are generally lower in the coastal river basins than in the Rhone and its tributary basins. Our simulations compare well with other literature estimates, in particular the ones of Petelet-Giraud and Negrel (2007) for the Herault River and of Serrat et al. (2001) for the Tet River. Only for the Agly River, our estimates are somewhat lower than in the study of Serrat (1999), despite the fact that we integrated their data in our study. Also for the Rhone River, the value of $88 \mathrm{t} \mathrm{km}^{-2} \mathrm{yr}^{-1}$ is close to previous estimates. Sediment yields in this river are greater than in all coastal rivers, confirming its outstanding role in the entire Gulf of Lions drainage basin. This outstanding role also holds for entire France. Delmas et al. (2012) 
Table 4

Name and code of water gauging stations, SPM monitoring stations and irregular SPM sampling of each river.

\begin{tabular}{|c|c|c|c|c|}
\hline \multirow[t]{2}{*}{ Rivers } & \multicolumn{2}{|c|}{ Water gauging stations } & \multicolumn{2}{|l|}{ SPM monitoring stations and irregular SPM sampling } \\
\hline & Station name & Station code & Station name & Station code \\
\hline Tech & Argeles & Y0284060 & Elne & 168000 \\
\hline \multirow[t]{2}{*}{ Tet } & Perpignan & Y0474030 & St Marie la Mer Villelongue-Salanque (MOOSE) & 172100 \\
\hline & Perpignan & Y0474030 & & \\
\hline Agly & Estagel & Y0664040 & St Laurent-Salanque & 175000 \\
\hline Aude & Moussan [viaduc] & Y1612010 & Salles & 6180900 \\
\hline Orb & Beziers & Y2584010 & Villeneuve-les-Beziers & 6188500 \\
\hline Herault & Agde & Y2372010 & Florensac & 184000 \\
\hline Rhone & Beaucaire & V7200010 & Arles (MOOSE) & \\
\hline Saone & Macon [amont] & U4300010 & Fleurville & 06045800 \\
\hline Upper Rhone & Lyon [Perrache] & V3000015 & Jons & 06092500 \\
\hline Isere & Beaumont-monteux & W3540010 & Eymeux & 06148200 \\
\hline Durance & St-paul & X3000010 & Vinon-Sur-Verdon & 06159800 \\
\hline Ardeche & St-martin & V5064010 & Vallon-Pont-d'arc 2 & 06115090 \\
\hline Ceze & Roque-sur-ceze & V5474010 & Chusclan & 06121000 \\
\hline Rhone & St Ternay & V3130020 & Rhone a Chasse sur Rhone & 06098000 \\
\hline Rhone & St Valence & V4010010 & Rhone a Beauchastel 1 & 06106600 \\
\hline
\end{tabular}

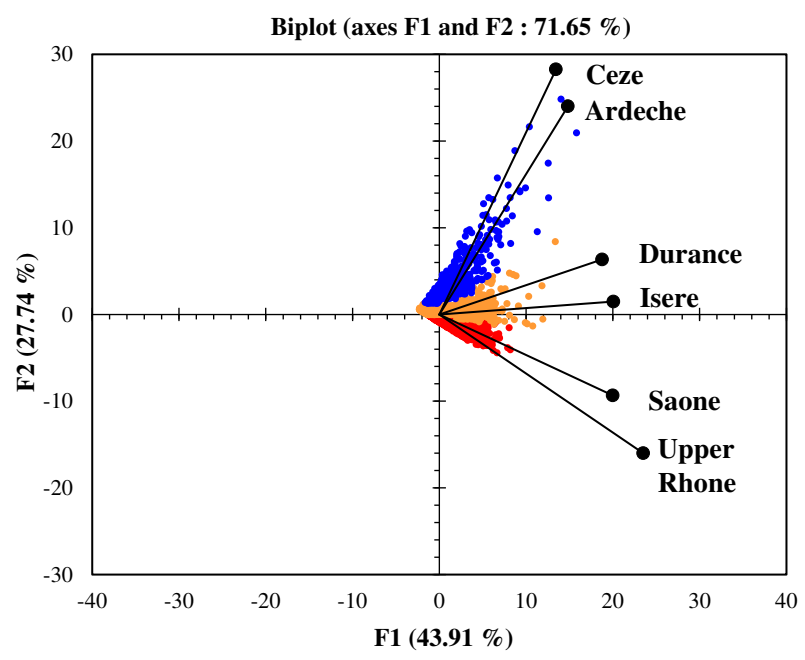

Fig. 2. Results of the principal component analysis (PCA) on daily discharge of the six Rhone tributaries over the study period. Correlation circles of the six tributary vectors in the $\mathrm{F} 1 \times \mathrm{F} 2$ dimension are represented by black circles. The position in this factorial design allows identification of three major groups, which reflect the relative importance of Mediterranean floods (Ardeche-Ceze, blue color), Northern floods (Upper Rhone-Saone, red color) and South-Alpine floods (Durance-Isere, orange color) in the Rhone discharge at Beaucaire. Each axis (F1, F2) has a size effect. The data for which the total discharge at Beaucaire is high (flood) present elevated values on one or both axis. When discharge at Beaucaire is low, data are close to the origin and the dominant tributary contributions cannot be identified. (For interpretation of the references to color in this figure legend, the reader is referred to the web version of this article.)

noticed that the Rhone alone probably accounts for $60 \%$ of the total sediment export from continental France to the Sea, although it drains only less than $20 \%$ of the corresponding area. About $100-150$ years ago, when damming was almost absent, natural sediment fluxes of this river may still have been 2-5 times greater than today (Surell, 1847; Pardé, 1925, 1947; Milliman and Meade, 1983).

Table 5a also shows that the Durance and Isere tributaries are the major sources of SPM in the Rhone River. Sediment yields are here $151 \mathrm{t} \mathrm{km}^{-2} \mathrm{yr}^{-1}$ and $135 \mathrm{t} \mathrm{km}^{-2} \mathrm{yr}^{-1}$, respectively. High mechanical erosion rates are well known in these drainage basins and related to the formation of badlands on highly erodible rock formations (marls and shales). For example, Mano et al. (2009) reported for the years 2001-2004 sediment yields as high as
$450-800 \mathrm{t} \mathrm{km}^{-2} \mathrm{yr}^{-1}$ in four small $\left(<100 \mathrm{~km}^{2}\right)$ and medium size $\left(<1000 \mathrm{~km}^{2}\right)$ catchments of the Isere and Durance rivers. Dumas (2008) found an average sediment yield of $349 \mathrm{t} \mathrm{km}^{-2} \mathrm{yr}^{-1}$ for the Isere at Grenoble (about half of the drainage basin we considered) during 1995-2005, with peak contributions over $2500 \mathrm{t} \mathrm{km}^{-2} \mathrm{yr}^{-1}$ from a single small watershed. In the Durance drainage basin, values of $360 \mathrm{t} \mathrm{km}^{-2} \mathrm{yr}^{-1}$ have been found by Navratil et al. (2011) for the Galabre catchment $\left(35 \mathrm{~km}^{2}\right)$ and peak values of $10,000 \mathrm{t} \mathrm{km}^{-2} \mathrm{yr}^{-1}$ at the plot scale were reported by Mathys et al. (2003) in badlands of the Draix observatory.

The great spatial variability of average sediment yields in the Gulf of Lions drainage basin offers an interesting framework for examination of the dominant environmental controls of average river sediment yields (SY). When only considering the coastal river basins, our data suggest that the latter are mainly controlled by the torrential character of the water flow in these rivers (Tr, see Table 2$)$, with $r^{2}=0.84$ between both parameters $(n=6)$. For the tributaries of the Rhone (not considering the Rhone itself), the highest correlation is found with the portion of sedimentary rocks in elevated areas (SRe, see Table 1). Correlation between both parameters is here $r^{2}=0.81(n=6)$. Merging both groups leads to the formulation of a multiple regression model which also adds average basin elevation $(Z)$ to the predictive variables. It explains about $90 \%$ of the detected variability:

$$
\begin{aligned}
& \mathrm{SY}=3.97 \mathrm{Tr}+5.13 \mathrm{SRe}+0.04 \mathrm{Z}-41.19 \\
& \mathrm{r}^{2}=0.90, \quad \mathrm{n}=12, \quad \mathrm{p} \leqslant 0.01
\end{aligned}
$$

Since variability of SY is reduced in the coastal river basins compared to the entire data set, lithology and basin elevation exert the dominant controls on SY in the Gulf of Lions drainage basin. Notice also that in all the regressions we performed, basin area had obviously no influence on sediment yields.

\subsection{Sediment budgets in the Rhone River basin}

Summing the tributary basins for which we produced average SPM fluxes represents $76 \%$ of the Rhone River basin. Coverage is rather complete and raises the question whether the amount of sediments that is exported at the river mouth might be in equilibrium with the amount of sediments supplied by the tributaries. The problem is that for the missing $24 \%$ of the drainage basin, flux estimates are needed too, but cannot be determined independently. They can only be derived indirectly via a nested catchment approach (Gay et al., 2014), starting from the assumption that they 


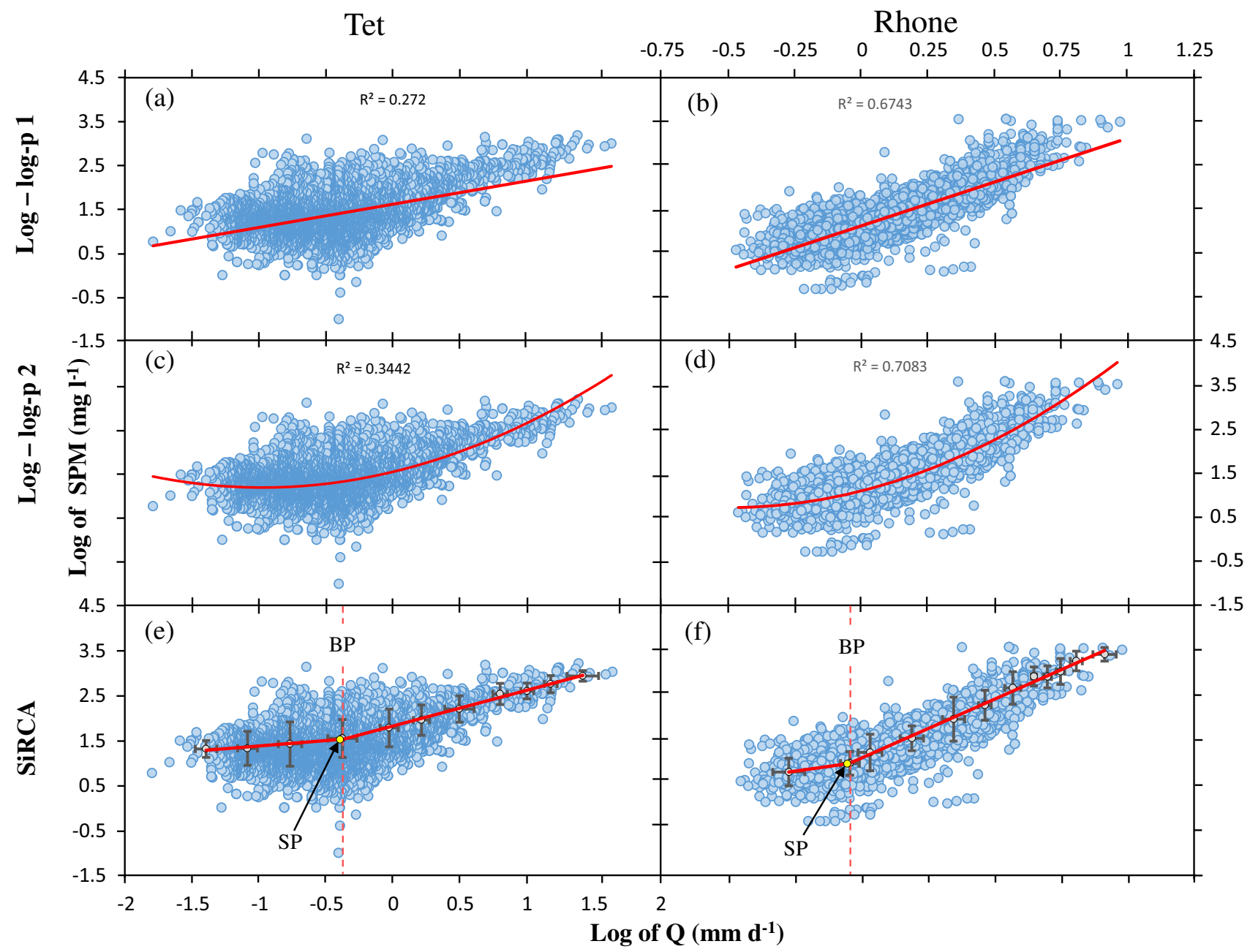

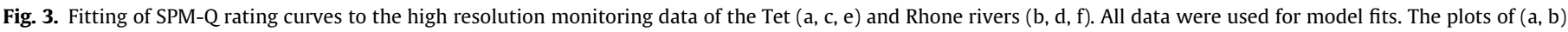

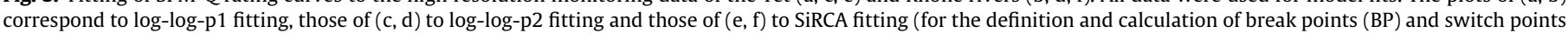
(SP), see Section 3.2). For further explanations, see text.

reflect the difference between the fluxes which leave and which enter the basin.

We therefore also applied SiRCA to two additional stations along the main Rhone River course, which are the stations Ternay and Valence (see Fig. 5). This divides the non-monitored downstream part of the Rhone basin into the three sub-basins DR1, DR2 and DR3 (see Fig. 1; DR stands for downstream Rhone). For the corresponding SPM budgets, DR1 is considered to represent the difference between the fluxes at Rhone-Ternay and Saone plus Upper Rhone and includes the tributaries of Veyle and Azergues. DR2 is the difference between Rhone-Valence and Rhone-Ternay plus Isere (including the tributaries of Gier, Gere, Galaure and Doux) and DR3 is the difference between Rhone-Beaucaire and the sum of Rhone-Valence, Durance, Ceze and Ardeche. DR3 is more than twice as great as DR1 and DR2 and includes the tributaries Eyrieux, Drome, Roubion, Lez, Aigue, Ouveze and Gardon.

Fig. 6 depicts the long-term sediment yields from upstream to downstream in the different river basins of Rhone River, together with the corresponding values for the downstream parts DR1, DR2 and DR3. Because we disposed here longer discharge records than for the coastal rivers, they cover the period 1969-2013. Average SY values can therefore be slightly different compared to those in Table 5a. Sediment yields in the DR basin parts increase from upstream to downstream from 65 to $132 \mathrm{t} \mathrm{km}^{-2} \mathrm{yr}^{-1}$. This lies in the range which is defined by the tributary SY. One may neverthe- less be surprised that in DR3, SY are as great as for the Isere and Durance catchments, the two major source regions of SPM in the Rhone River. Interestingly, when omitting the years 1993, 1994 and 2002, 2003 in our calculations, characterized by exceptional flooding, we find that SY in DR3 drops to $77 \mathrm{t} \mathrm{km}^{-2} \mathrm{yr}^{-1}$. Also in the other southern basin parts, significant decreases appear (but less spectacular than in DR3), but not in the northern basin parts.

\subsection{Sediment delivery to the Gulf of Lions}

Our calculations finally allow to draw a complete picture of the riverine sediment delivery to the Gulf of Lions. The average longterm fluxes (1977-2013) are summarized in Fig. 7. The figure also proposes a breakdown of the Rhone fluxes into its tributary contributions and includes the loss of sediments from the Durance River to the Berre lagoon (about $0.260 \mathrm{Mt} \mathrm{yr}^{-1}$ ). The latter value was estimated from the study of Fiandrino (2004) for the years $<2000$, and successively adjusted to $0.060 \mathrm{Mt} \mathrm{yr}^{-1}$ for the years 2005 and later according to the information given by Picon and Bernard (2009).

The total amount of SPM discharged by the coastal rivers is $0.474 \mathrm{Mt} \mathrm{yr}^{-1}$, corresponding to only slightly more than $5 \%$ of the total solid discharge to the Mediterranean Sea in this area (Rhone and coastal rivers). Bourrin et al. (2006) and Delmas et al. (2012) estimated the coastal river inputs to 0.640 and $0.570 \mathrm{Mt} \mathrm{yr}^{-1}$, 

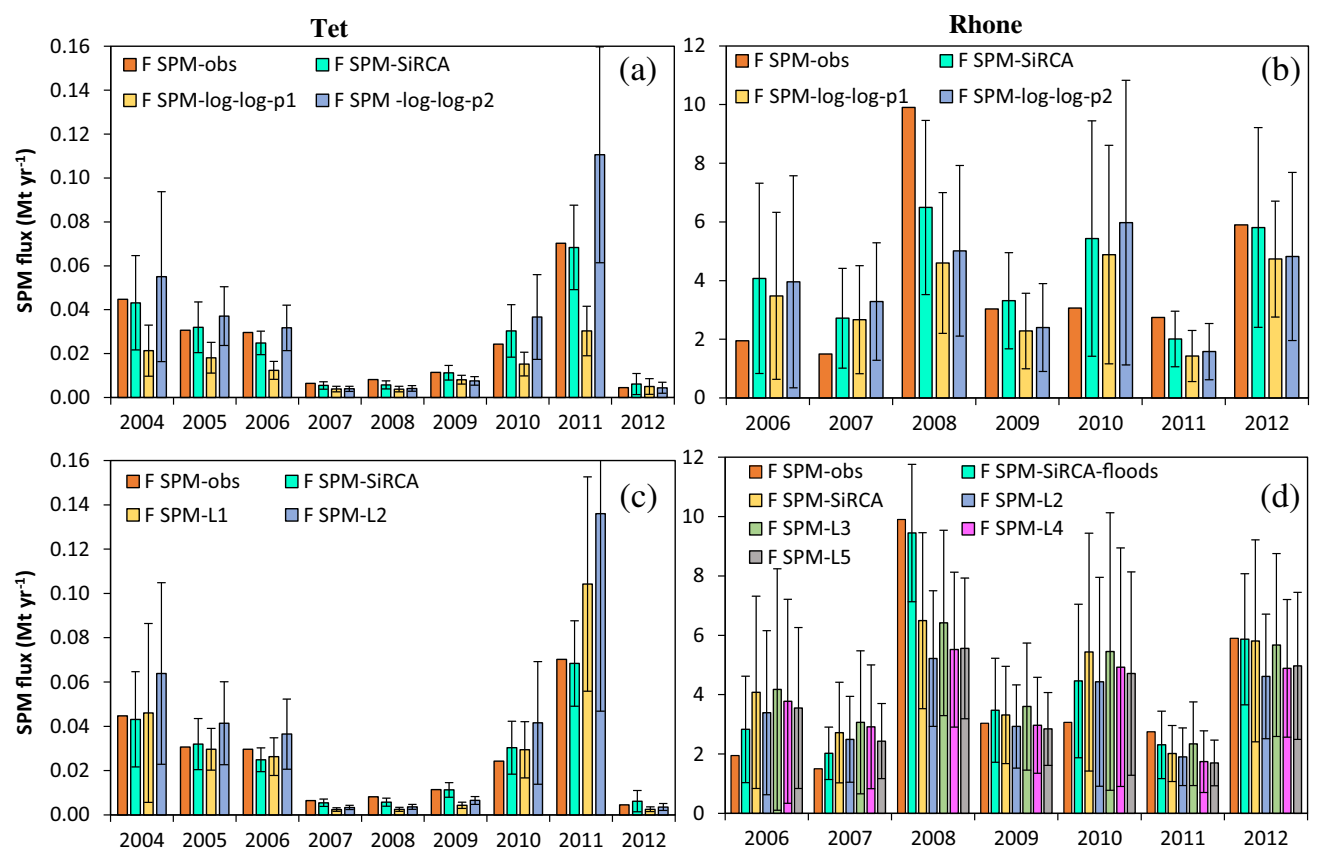

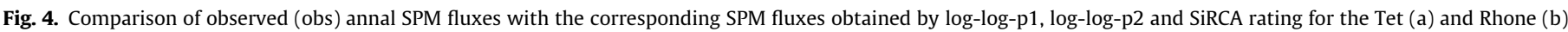

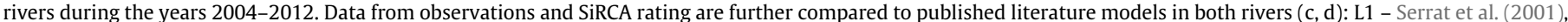

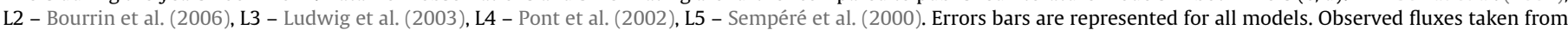

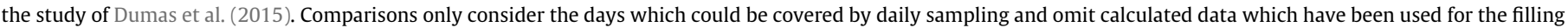
of data gaps. For further explanations, see text (and Dumas et al., 2015).

respectively. This is close to our value (in as much as they also considered some smaller rivers). The six coastal rivers of our study only cover part of the Gulf of Lions drainage basin west of the Rhone River. Applying the average value of the coastal river sediment yields to the missing basin area suggests that probably up to $1 \mathrm{Mt} \mathrm{yr}^{-1}$ of SPM may reach the Golf of Lions apart from the Rhone River inputs (or about $10 \%$ of the total inputs). However, taking into account the numerous coastal lagoons which can intercept the river sediments in this region (see Fig. 1), this value is certainly overestimated.

In terms of the long-term average sediment supply, the coastal rivers play only a minor role compared to the Rhone River. At yearly time scales, their relative importance can be more significant. Fig. 8 depicts the yearly SPM fluxes of the Rhone and of the merged coastal rivers for the period 1977-2013, together with the relative contributions of the coastal rivers in the total fluxes. The latter varied between 1\% in 1983 and 27\% in 2011. Both river systems are not necessarily in phase. Peak discharges for the Rhone occurred in 1993/1994 and in 2002, whereas for the coastal rivers, this was in 1996 and in 2011. At seasonal scales (Fig. 9), variability between both systems is even more important. During spring and autumn, the seasons when flash-floods are likely, the coastal rivers contribute to up to one quarter of the total sediment discharge in $25 \%$ of the investigated years. Peak contributions for individual years often attend up to $90 \%$. During the summer month, however, the coastal rivers have almost no importance for the total riverine sediment discharge to the Gulf of Lions.

Fig. 8 also shows that neither the Rhone River nor the coastal rivers depict clear long-term trends in their annual SPM discharges. This is confirmed when performing statistical analyses for trends on the basis of the Mann-Kendal test (see Section 3.3.4). Because of the great year to year variability of the river SPM fluxes in the studied rivers, in particular for the smaller Mediterranean ones, trend analyses often do not allow conclusive results (the corresponding $\mathrm{CV}$ values are greater than 1 ). Among the Rhone River tributaries, however, a certain number of significant negative trends $(\mathrm{p} \leqslant 0.01)$ were detected for the $1977-2013$ period. This concerns the Saone, Isere and DR1 basins. On the other hand, SPM fluxes from the Ardeche basin increased during the same time, but with great inter-annual variability (CV is here slightly greater than 1, which questions the statistical significance of this trend). Our results hence indicate that SPM fluxes in the Rhone River were not in a steady state with respect to the different source regions and may have been affected by long-term climate variability and/ or recent climate change.

\section{Discussion and conclusions}

Our study produces a holistic view on river sediment fluxes in the Gulf of Lions drainage basin, a major source region for the land-to-sea transfer of terrestrial materials to the Mediterranean Sea. This region is characterized by a great variability of hydroclimatic, morphological, lithological and major land use characteristics, which is particularly interesting for a better understanding of the general controls of these fluxes at larger scales. Detailed characterization of their spatio-temporal variability at the level of a major shelf area is also highly useful for oceanographic investigations which focus on their potential impacts and fates in the coastal system.

Such a holistic approach previously suffered from data gaps and differences in data quality with regard to observations. We therefore started from the development of a simple and robust approach for the prediction of average SPM fluxes. SiRCA is not fundamentally different compared to most literature approaches, as it uses SPM-Q rating curves to predict the fluxes. It mainly intends to strengthen the SPM measurement for high-discharge conditions, generally under-represented in SPM-Q data sets, in order to avoid possible biases in the resulting fluxes. SiRCA always produced two distinct regression lines which cross at individual discharge thresholds (i.e. a few millimetres per day), separating the rating curve in a transport-dominated and erosion-dominated model part. Such behaviour cannot be fitted 


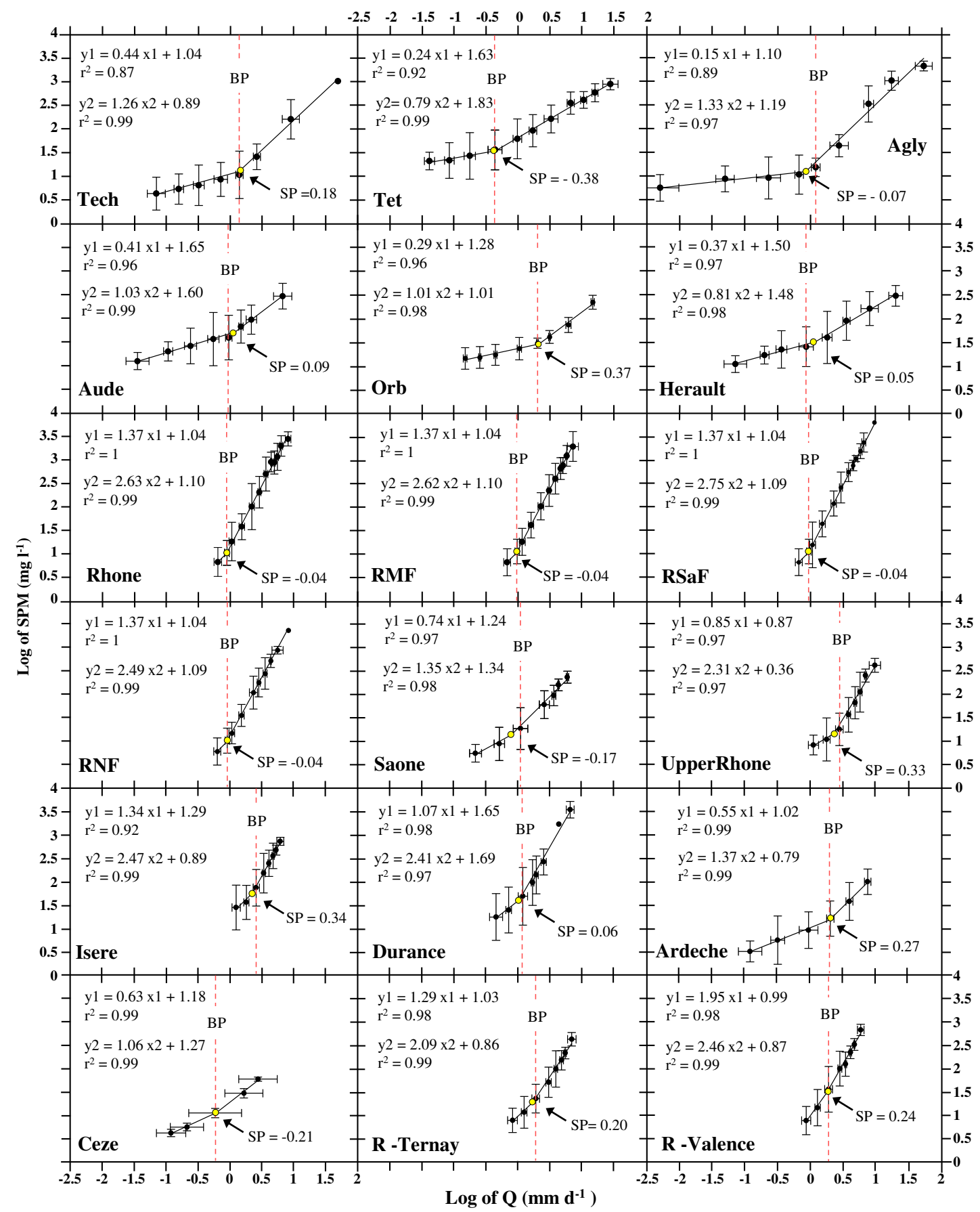

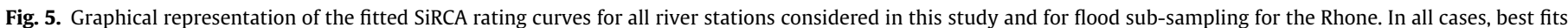

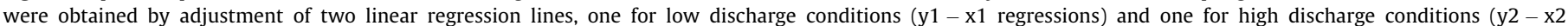

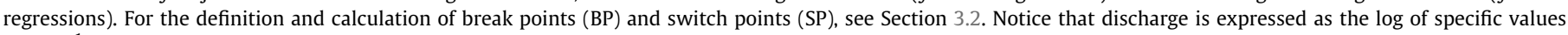

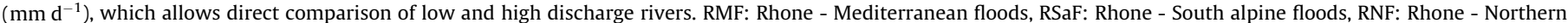
floods, R-Ternay: Rhone at Ternay, R-Valence: Rhone at Valence.

with a single log-log regression line, as this is done in classical rating curve approaches. Second order polynomial regressions better fit in these cases but also include the risk of overestimating the fluxes during peak discharges. Because of their low discharge values during the dry seasons, the existence of switch points is particularly visible in the coastal rivers. Although their average sediment fluxes are only moderate compared to the Rhone River, consideration of these river systems in our data was highly useful for the optimisation of appropriate rating curve models in the study region.
Validation of SiRCA could be done through comparison with high resolution monitoring of the Tet and Rhone rivers, and via comparison with other literature studies. Our long term means we calculated confirm the outstanding role of the Rhone River in the Gulf of Lions drainage basin (and entire continental France), not only in terms of its elevated sediment loads, but also in terms of its elevated sediment yields. This is largely because of exceptional erosion rates in the Isere and Durance tributaries, associated with outcrops of highly erodible sedimentary rocks. Consequently, when confronted to the environmental drainage 
Table 5a

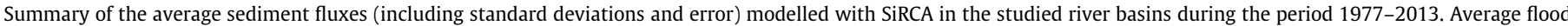
contributions are also shown (\% SPM floods). For comparison with previous literature studies, see Table 5b.

\begin{tabular}{|c|c|c|c|c|c|c|}
\hline Rivers (1977-2013) & RSF (Mt) & $\mathrm{SL}\left(\mathrm{Mt} \mathrm{yr}^{-1}\right)$ & Error (\%) & $\mathrm{SL}\left(\mathrm{Mt} \mathrm{yr}^{-1}\right)$ & 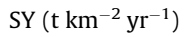 & \% SPM flux (flood) \\
\hline Tech & 1.84 & 0.050 & 27.02 & \pm 0.049 & 69 & 81 \\
\hline Tet & 1.68 & 0.045 & 27.2 & \pm 0.035 & 33 & 51 \\
\hline Agly & 2.46 & 0.066 & 33.5 & \pm 0.077 & 63 & 91 \\
\hline Aude & 3.75 & 0.101 & 32.6 & \pm 0.064 & 19 & 44 \\
\hline Orb & 2.37 & 0.064 & 30.2 & \pm 0.047 & 42 & 58 \\
\hline Herault & 5.69 & 0.154 & 32.5 & \pm 0.098 & 60 & 63 \\
\hline Rhone & 312.46 & 8.445 & 17.4 & \pm 4.538 & 88 & 40 \\
\hline Saone & 41.86 & 1.131 & 29.0 & \pm 0.392 & 39 & 25 \\
\hline Upper Rhone & 35.96 & 0.972 & 33.5 & \pm 0.409 & 48 & 32 \\
\hline Isere & 59.92 & 1.620 & 32.5 & \pm 0.764 & 135 & 30 \\
\hline Durance & 60.07 & 1.623 & 28.9 & \pm 1.456 & 151 & 65 \\
\hline Ardeche & 9.27 & 0.251 & 19.7 & \pm 0.238 & 104 & 82 \\
\hline Ceze & 4.13 & 0.112 & 32.4 & \pm 0.093 & 81 & 70 \\
\hline
\end{tabular}

Table 5b

Summary of riverine sediment yields for the previous literature studies in the Gulf of Lions.

\begin{tabular}{|c|c|c|c|}
\hline Rivers & Study & Study period & $\mathrm{SY}\left(\mathrm{t} \mathrm{km}^{-2} \mathrm{yr}^{-1}\right)$ \\
\hline Tet & Serrat et al. (2001) & 1980-1999 & 40 \\
\hline Agly & Serrat (1999) & 1966-1996 & 91 \\
\hline Herault & Petelet-Giraud and Negrel (2007) & $1971-2004$ & 58 \\
\hline Rhone & $\begin{array}{l}\text { Sempéré et al. (2000) } \\
\text { Ludwig et al. (2003) } \\
\text { Pont (1997) } \\
\text { Pont et al. (2002) } \\
\text { Delmas et al. (2012) }\end{array}$ & $\begin{array}{l}1987-1996 \\
1961-1997 \\
1967-1996\end{array}$ & $\begin{array}{l}103 \\
88 \\
64 \\
77 \\
115\end{array}$ \\
\hline
\end{tabular}

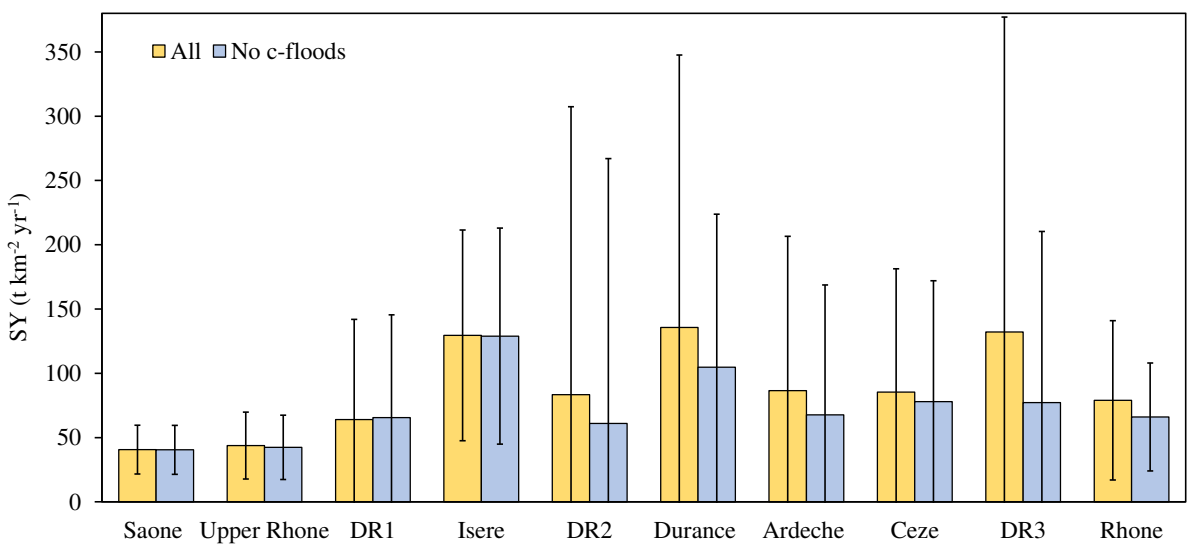

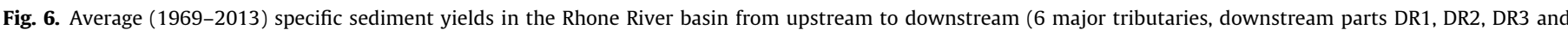

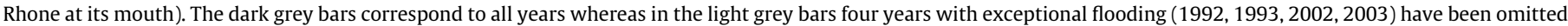
(no century-floods).

basin characteristics, multiple regression analyses indicate that lithology is the most important controlling factor for sediment yields in the study region. Especially the existence of erodible sedimentary rocks in the elevated basin parts seems to be responsible for high erosion rates. Also in the coastal river basins, sedimentary rocks can be abundant (Table 1 ). But here, most of the elevated headwater regions are formed by plutonic and metamorphic shield rocks, which explain the generally lower sediment yields in these rivers.

Basin area has obviously no influence on sediment yields. The general concept of increased sediment retention in larger river basins, although tempting from a conceptual point of view, cannot be confirmed by our data. Previous studies already stated that the often reported observations of greater sediment yields in smaller river basins may simply translate their greater probability to rep- resent extremes in the real controlling factors (e.g., Vanmaercke et al., 2011). The torrential character of water flow (Tr), also retained in our regression model of equation (iii) and probably the dominant control in the group of coastal rivers (see Section 4.2), may be a good example for this. This parameter is clearly anticorrelated to the logarithm of basin area in our data $\left(r^{2}=0.83\right.$, $\mathrm{n}=12$ ). Also morphological extremes (average basin elevation is the third parameter which is retained in our regression model) are more likely in smaller basins than in larger ones (Ludwig and Probst, 1998).

The question if basin-internal sediment retention is important in the study region can also be studied in the Rhone River basin, where we propose for the first time a complete breakdown of the fluxes at the river mouth into their different contributions from further upstream. Assuming that sediment delivery ratios are $\leqslant 1$, 


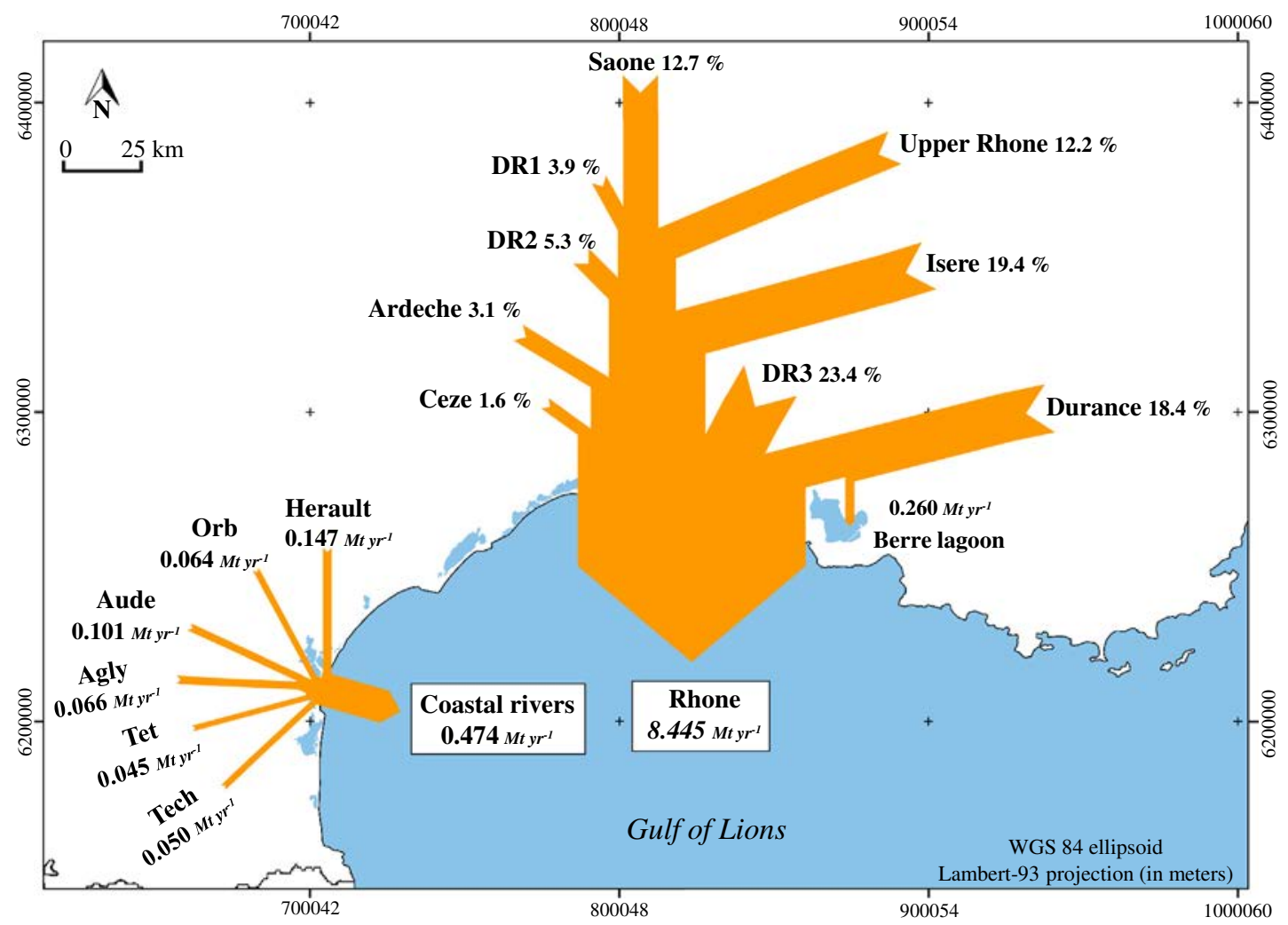

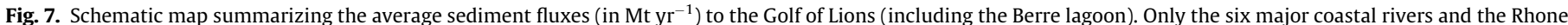
River are represented. For the latter, the flux is differentiated according to the major tributaries and different source regions further upstream (in \% of the total fluxes).

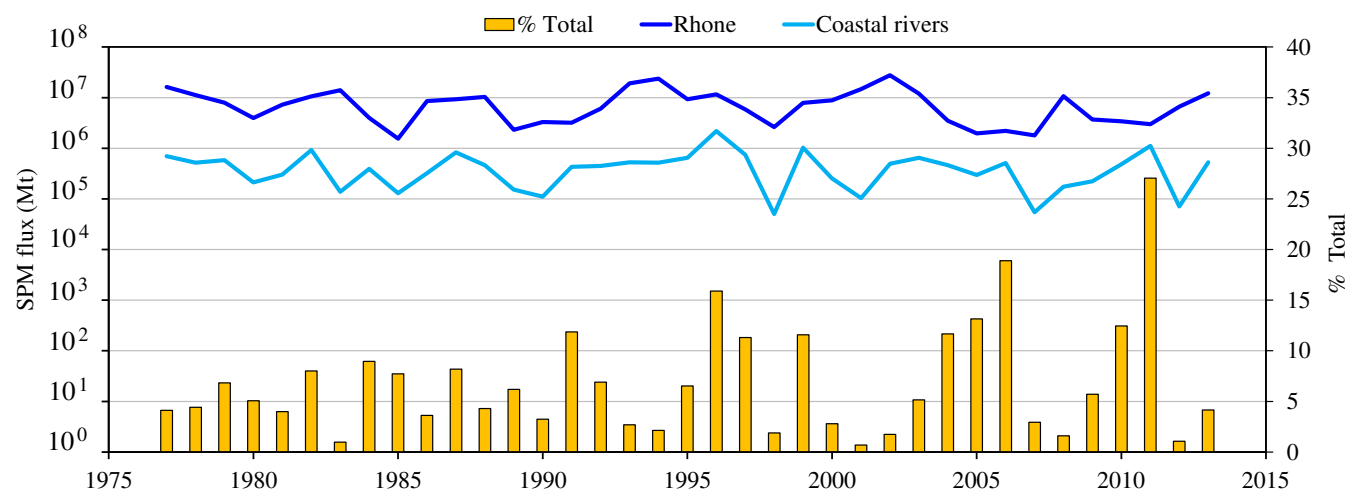

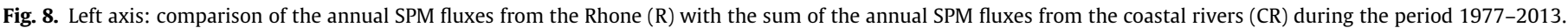
Right axis: contribution (\% total) of the coastal rivers in the total SPM fluxes (coastal rivers and Rhone) to the Gulf of Lions.

one should expect that the amount of sediments supplied by the tributaries surpasses the amount of sediments discharged at the river mouth. On the other hand, one could also argue that, because of the much greater SPM fluxes in the Rhone River during predamming times (see Section 4.2), the river system is actually in excess of sediments and export fluxes surpass the supply from the tributaries.

Our average SPM fluxes in the Rhone River basin are surprisingly well equilibrated from upstream to downstream. This does, of course, not mean that sediment retention does not occur in the uppermost headwater basins. But at the level of the major tributaries, sediment retention is probably of minor importance. The downstream sediment yields we obtain for the basin parts which lack direct measurements (DR1, DR2, and DR3) are nevertheless elevated, which does not exclude an underestimation of the tributary fluxes from upstream. But these high sediment yields are mainly restricted to the lowermost DR3 catchment and strongly related to the extreme floods of the Rhone during recent years. This corroborates with our finding that major upstream source regions (i.e. the Saone and Isere river basins) show decreasing SPM discharge trends during the study period, probably compensated by increased SPM mobilisation from the Mediterranean basin parts further downstream. It is therefore not excluded that elevated sediment yields in the DR3 at least partly reflect the re-mobilisation of older sediments.

One may finally conclude from our data that sediment inputs into the Gulf of Lions from the coastal rivers can be neglected compared to those of the Rhone River. On average, they account for only slightly more than $5 \%$ of the total inputs. However, we also demonstrated that long term averages are not very meaningful in 


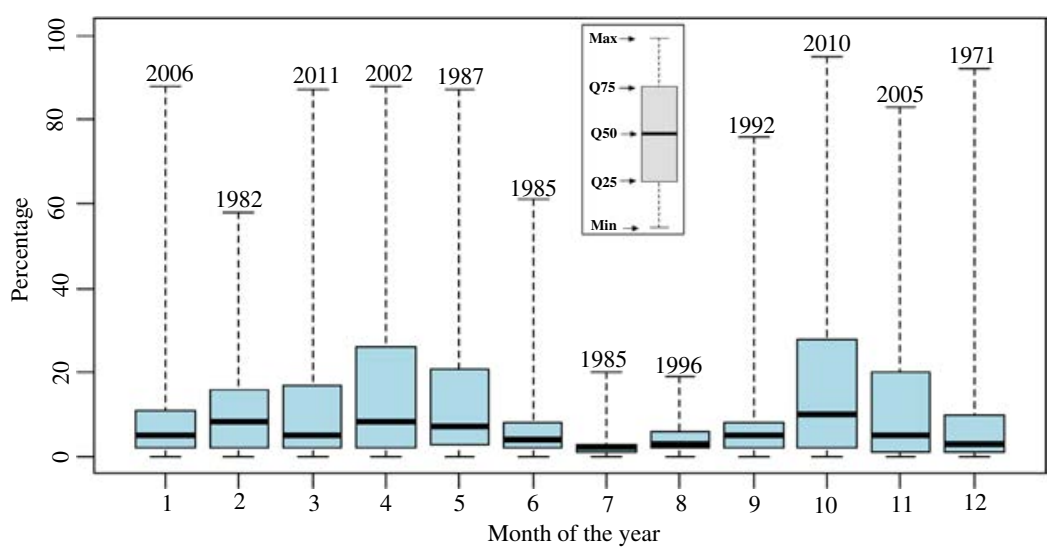

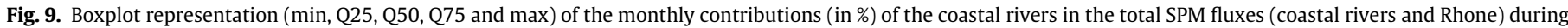
the period 1977-2013. For the maximum values, the corresponding years are shown on top.

order to evaluate the potential impact of riverine SPM in the marine domain. At seasonal and event-based time scales, the relative importance of these inputs compared to the Rhone River inputs can strongly increase and even become dominant. Further evaluation of the impact of riverine SPM inputs into the coastal domain requires fully coupling of terrestrial flux simulations with simulations of the prevailing hydrodynamic conditions in the marine system. Data sets as we produced with our study can facilitate this purpose and represent another step towards the realisation of coupled source-to-sink approaches in coastal environmental studies.

\section{Acknowledgements}

This work was supported by the National Centre of Scientific Research - France (Centre National de la Recherche Scientifique France, CNRS) through the attribution of a PhD grant to MS and through previous funding of the long-term environmental observation program ORME (Observatoire Régional Méditerranéen de l'Environnement). Additional financial support was provided by the Mediterranean Ocean Observing System for the Environment (MOOSE). We are grateful to two anonymous reviewers for their valuable and useful comments during the review process.

\section{References}

AERMC, 2015. Rhone-Mediterranean and Corsica Water Agency. <http://www. eaurmc.fr $/>$ (Consulted in January 2015).

Asselman, N.E.M., 2000. Fitting and interpretation of sediment rating curves. J. Hydrol. 234, 228-248.

Bourrin, F. Durrieu de Madron, X., Ludwig, W., 2006. Contribution of the study of coastal rivers and associated prodeltas to sediment supply in North-western Mediterranean Sea (Gulf of Lions). Life Environ. 56 (4), 307-314.

Bourrin, F., Friend, P.L., Amos, C.L., Manca, E., Ulses, C., Palanques, A., Durrieu de Madron, X., Thompson, C.E.L., 2008. Sediment dispersal from a typical Mediterranean flood: The Têt River, Gulf of Lions. Cont. Shelf Res. 28, 18951910. http://dx.doi.org/10.1016/j.csr.2008.06.005.

Chatterjee, S., Hadi, A.S., 2006. Regression analysis by example. In: Shewhart, W.A., Wilks, S.S. (Eds.), Wiley Series in Probability and Statistics, fourth ed. John Wiley and Sons, Inc.

CLC, 2006. CORINE Land Cover Hosted at the French Ministry of the Environment and of Sustainable Development. <http://www.statistiques.developpementdurable.gouv.fr/> (Consulted in January 2015).

Cheviron, B., Delmas, M., Cerdan, O., Mouchel, J., 2014. Calculation of river sediment fluxes from uncertain and infrequent measurements. J. Hydrol. 508, 364-373.

Delmas, M., Cerdan, O., Cheviron, B., Mouchel, J.-M., Eyrolle, F., 2012. Sediment export from French rivers to the sea. Earth Surf. Proc. Land. 37 (7), 754-762.

Delmas, M., Cerdan, O., Mouchel, J.-M., Garcin, M., 2009. A method for developing a large-scale sediment yield index for European river basins. J. Soils Sediments 9 (6), 613-626.

De Vente, J., Poesen, J., Verstraeten, G., Van Rompaey, A., Govers, G., 2008. Spatially distributed modelling of soil erosion and sediment yield at regional scales in Spain. Global Planet. Change 60 (3-4), 393-415.
Dumas, D., 2008. Bilan d'érosion d'un cours d'eau alpin: l'Isère à Grenoble (France). Zeitschrift für Geomorphologie 52 (1), 85-103.

Dumas, C., Ludwig, W., Aubert, D., Eyrolle, F., Raimbault, P., Gueneugues, A., Sotin, 2015. Riverine transfer of anthropogenic and natural trace metals to the Gulf of Lions (NW Mediterranean Sea). Appl. Geochem. 58, 14-25.

Durrieu de Madron, X., Abassi, A., Heussner, S., Monaco, A., Aloisi, J.-C., Radakovitch O., Giresse, P., Buscail, R., Kerhervé, P., 2000. Particulate matter and organic carbon budgets for the Gulf of Lions (NW Mediterranean). Oceanol. Acta 23 (6), 717-730.

Durrieu de Madron, X., Ludwig, W., Civitarese, G., Gacic, M., Ribera d'Alcalà, M. Raimbault, P., Krasakopoulou, E., Goyet, C., 2009. Shelf-slope nutrients and carbon fluxes in the Mediterranean Sea. In: Liu, K.K., Atkinson, L., Quinones, R., Talaue-McManus, L. (Eds.), Carbon and Nutrient Fluxes in Continental Margins. A Global Synthesis, Global Change - The IGBP Series, vol. XII. Springer-Verlag, pp. 364-383.

Fiandrino, 2004. Apports de matières en suspension par les fleuves côtiers à l'Etang de Berre (Bouches du Rhône, France). Etudes de Géographie Physique Supplément au n XXXI. Université Sophia Antipolis, Nice, France. p. 260.

Gay, A., Cerdan, O., Delmas, M., Desmet, M., 2014. Variability of suspended sediment yields within the Loire river basin (France). J. Hydrol. 519, 1225-1237.

Gumbel, E.J., 1958. Statistics of Extremes. Columbia University Press, New York.

Harrison, C.G.A., 2000. What factors control mechanical erosion rates? Int. J. Earth Sci. 88 (4), 752-763.

Hijmans, R.J., Cameron, S.E., Parra, J.L., Jones, P.G., Jarvis, A., 2005. Very high resolution interpolated climate surfaces for global land areas. Int. J. Climatol. 25, 1965-1978.

Hydro, 2015. Hydrological Data Bank Hosted at the French Ministry of the Environment and of Sustainable Development. <http://www.hydro.eaufrance. $\mathrm{fr} /$ index.php> (Consulted in January 2015).

IGN, 2015. Institut National de l'Information Géographique et Forestière. <http:// professionnels.ign.fr/bdalti> (Consulted in January 2015).

Kendall, M.G., 1975. Rank Correlation Methods, fourth ed. Charles Griffin, London.

Lespinas, F., Ludwig, W., Heussner, S., 2009. Impact of recent climate change on the hydrology of coastal Mediterranean rivers in Southern France. Climatic Change 99, 425-456.

Lespinas, F., Ludwig, W., Heussner, S., 2014. Hydrological and climatic uncertainties associated with modeling the impact of climate change on water resources of small Mediterranean coastal rivers. J. Hydrol. 511, 403-422.

Ludwig, W., Dumont, E., Meybeck, M., Heussner, S., 2009. River discharges of water and nutrients to the Mediterranean Sea: major drivers for ecosystem changes during past and future decades? Prog. Oceanogr. 80, 199-217.

Ludwig, W., Meybeck, M., Abousamra, F., 2003. Riverine transport of water sediments, and pollutants to the Mediterranean Sea. UNEP MAP Technical Report, Series 141, Athens.

Ludwig, W., Probst, J.-L., 1998. River sediment discharge to the oceans: present-day controls and global budgets. Am. J. Sci. 296, 265-295.

Mallows, C.L., 1973. Some comments on CP. Technometrics 15, 661-675.

Mann, H.B., 1945. Non-parametric test against trend. Econometrica 13, 245-259.

Mano, V., Némery, J., Belleudy, P., Poirel, A., 2009. Assessment of suspended sediment transport in four alpine watersheds (France): influence of the climatic regime. Hydrol. Process. 22. http://dx.doi.org/10.1002/hyp.7178.

Mathys, N., Brochot, S., Meunier, M., Richard, D., 2003. Erosion quantification in the small marly experimental catchments of Draix (Alpes-de-Haute-Provence, France). calibration of the ETC rainfall-runoff-erosion model. Catena 50, 527 548.

Meybeck, M., Laroche, L., Durr, H.H., Syvitski, J.P.M., 2003. Global variability of daily total suspended solids and their fluxes in rivers. Global Planet. Change 39, 6593.

Milliman, J.D., Meade, R.H., 1983. World-wide delivery of river sediment to the oceans. J. Geol. 91 (1), 1-21. 
Milliman, J.D., Syvitski, J.P.M., 1992. Geomorphic/tectonic control of sediment discharge to the ocean: the importance of small mountainous rivers. J. Geol., 525-544

Navratil, O., Esteves, M., Legout, C., Gratiot, N., Nemery, J., Willmore, S., Grangeon, T., 2011. Global uncertainty analysis of suspended sediment monitoring using turbidimeter in a small mountainous river catchment. J. Hydrol. 398 (3-4), 246259.

Ollivier, P., Hamelin, B., Radakovitch, O., 2010. Seasonal variations of physical and chemical erosion: a three-year survey of the Rhone River (France). Geochim. Cosmochim. Acta 74, 907-927.

Pardé, M., 1925. Le régime du Rhone. Etude hydrologique. 1ère partie. Etude générale (ed. Masson). Université de Lyon, Institut des Etudes Rhodaniennes, Paris. p. 887.

Pardé, M., 1947. Quelques nouveautés sur le régime du Rhone. Etudes rhodaniennes de l'université de Lyon. p. 172.

Petelet-Giraud, E., Negrel, Ph., 2007. Apport de matières en suspension en Méditerranée: le rôle des crues dans le bilan des exportations du bassinversant de l'Hérault. TSM 10, 55-69.

Picon, P., Bernard, G., 2009. Gestion intégrée de l'étang de Berre: des études opérationnelles pour sa réhabilitation.

Pont, D., 1997. Les débits solides du Rhône à proximité de son embouchure: données récentes (1994-1995). Revue de Géographie de Lyon 72, 23-33.

Pont, D., Simonnet, J.P., Walter, A.V., 2002. Medium-term changes in suspended sediment delivery to the ocean: consequences of catchment heterogeneity and river management (Rhône River, France). Estuar. Coast. Shelf Sci. 54, 1-18.

QGIS, 2015. Quantum Geographical Information System, version 2.8 (Wien) Downloaded in 2015 at <http://www.qgis.org/fr/site/>.

Raux, J., Copard, Y., Laignel, B., Fournier, M., Massei, N., 2011. Classification of worldwide drainage basins through the multivariate analysis of variables controlling their hydrosedimentary response. Global Planet. Change 76, $117-$ 127.

Roussiez, V., Heussner, S., Ludwig, W., Radakovitch, O., Durrieu de Madron, X., Guieu, C., Probst, J.-L., Monaco, A., Delsaut, N., 2012. Impact of oceanic floods on particulate metal inputs to coastal and deep-sea environments: a case study in the NW Mediterranean Sea. Cont. Shelf Res. 45, 15-26.

SANDRE, 2015. Service d'Administration Nationale des Données et Référentiels sur l'Eau. <http://www.sandre.eaufrance.fr/> (Consulted in January 2015).

Sempéré, R., Charrière, B., Cauwet, G., Van Wambeke, F., 2000. Carbon inputs of the Rhône River to the Mediterranean Sea: Biogeochemical implications. Global Biogeochem. Сy. 14, 669-681.

Serrat, P., 1999. Dynamique sédimentaire actuelle d'un système fluvial méditerranéen: l'Agly (France). CR Acad. Sci. Paris 329, 189-196.

Serrat, P., Ludwig, W., Navarro, B., Blazi, J.L., 2001. Variabilité spatio-temporelle des flux de matières en suspension d'un fleuve côtier méditerranéen: la têt (France). Comptes Rendus de l'Académie des Sciences-Series IIA-Earth and Planetary. Science 333 (7), 389-397.

Surell, E., 1847. Mémoire sur l'Amélioration des Embouchures du Rhone. Imprimerie Cévenole, Nîmes, France.

Vanmaercke, M., Poesen, J., Verstraeten, G., de Vente, J., Ocakoglu, F., 2011. Sediment yield in Europe: spatial patterns and scale dependency. Geomorphology 130, $142-161$.

Vivian, H., 1989. Hydrological changes of the Rhône River. In: Petts, G.E., Möller, H., Roux, A.L. (Eds.), Historical Change of Large Alluvial Rivers, Western Europe. J. Wiley and Sons, Chichester, pp. 57-77.

Walling, D.E., 1983a. The sediment delivery problem. J. Hydrol. 65 (1-3), 209-237.

Walling, D.E., 1983b. The sediment delivery problem. J. Hydrol. 65, 209-237.

Walling, D.E., Webb, B.W., 1985. Estimating the discharge of contaminants to coastal waters by rivers: some cautionary comments. Mar. Pollut. Bull. 16, 488492.

Walling, D.E., Fang, D., 2003. Recent trends in the suspended sediment loads of the World's rivers. Global Planet. Change 39, 111-126.

WorldClim, 2015. WorldClim - Global Climate Data. Free climate data for ecological modeling and GIS. (Consulted in January 2015).

Zeileis, A., Kleiber, C., Krämer, W., Hornik, K., 2003. Testing and dating of structural changes in practice. Comput. Stat. Data Anal. 44, 109-123. 